\title{
The Entanglements of Cultural Victimization and Cultural Healing within the Dominant White Apparatus: Tayo in Leslie Silko's Ceremony and Bigger in Richard Wright's Native Son
}

\author{
Sameer M. Al-Shraah* \\ Department of English, Al al-Bayt University, Mafraq, Jordan
}

Corresponding Author: Sameer M. Al-Shraah, E-mail: ssmmrr33@yahoo.com

\section{ARTICLE INFO}

Article history

Received: August 09, 2018

Accepted: October 05, 2018

Published: December 28, 2018

Volume: 9 Issue: 6

Advance access: November 2018

Conflicts of interest: None

Funding: None

\section{Key words:}

Cultural Domination,

Ethnicity,

Identity,

African American,

Native American,

Victimization,

Heritage

\begin{abstract}
The dominant white culture in the United States of America has always assumed the role of supremacy that victimizes other ethnicities and minorities and looked upon them as inferiors and unworthy of the privileges white people enjoy. Although the maltreatment of the Other-the non-white- differs from one ethnicity or minority to the other, it has always had sheer negative impacts on individuals as well as communities. This paper aims to show the victimization of African Americans as a community in America represented by the atrocity of Bigger and the victimization of Native Americans represented by trauma of Tayo. This paper will tackle the issue of victimization of the two communities-African American and native American-in general through the tough life journeys of the two protagonists of Richard Wright's Native Son and Leslie Silko's Ceremony and will try to show two different faces of maltreatment by the mainstream culture, but eventually same negative effects on both communities, African Americans and Native Americans. Thus, many Native Americans are subject to the mainstream culture instrumental policies that convince underprivileged ethnicities that they are integral part of the texture of the American society in time of national need. The irony is that such attitude is only meant to recruit non-whites to fight for the interest of the white supremacist apparatus. Silko eloquently displays patriotism and loyalty as the citizen who is eager and willing to fight and die for his people and country, and in that sense many Native Americans enlisted in the military so as to assert their masculinity. This, in fact, shows the negative effects of the pressure of white supremacist ideologies practiced against non-whites that they choose to act against their desires and choices in the hope that they will be accepted within the American social fabric. Finally, this paper explores some of the solutions available for the victimization and the atrocities of ethnic Americans, such as the communal support and the reconnection to one's heritage and cultural roots to heal the damaged self-image and psyches of ethnic Americans.
\end{abstract}

The dominant white culture in the United States of America has always assumed the role of supremacy that victimizes other ethnicities and minorities and looked upon them as inferiors and unworthy of the privileges white people enjoy. Although the maltreatment of the Other-the nonwhite- differs from one ethnicity or minority to the other, it has always had sheer negative impacts on individuals as well as communities. This paper aims to show the victimization of African Americans as a community in America represented by the atrocity of Bigger and the victimization of Native Americans represented by trauma of Tayo. This paper will tackle the issue of victimization of the two communitiesAfrican American and native American-in general through the tough life journeys of the two protagonists of Richard Wright's Native Son and Leslie Silko's Ceremony and will try to show two different faces of maltreatment by the mainstream culture, but eventually same negative effects on both communities, African Americans and Native Americans.

However, many critics focus on the contradictory relations between the white dominant culture and ethnic
American culture, ignoring the possibility of successfully healing the negative effects of cultural domination and victimization. Therefore, this paper explores some of the solution available to ethnic Americans, like the reframing of the cultural identity through reconnecting to the past. At the same time, this paper explore the negative effects of the absence of communal support on the ethnic individual who is left as a victim to the dominant white apparatus. Thus, ethnic memory will be explored as a "therapeutic mediation" for self-definition and as a treatment for the damaged self-image of using the dominant culture standards and values for self-definition and self-actualization.

Tayo is subject to sheer violence during World War II. He and many young Native Americans are subject to the mainstream culture instrumental policies that convince underprivileged ethnicities that they are integral part of the texture of the American society in time of national need. The irony is that such attitude is only meant to recruit non-whites to fight for the interest of the white supremacist apparatus. Silko eloquently displays the patriotic and loyal citizen as one who

Published by Australian International Academic Centre PTY.LTD.

Copyright (c) the author(s). This is an open access article under CC BY license (https://creativecommons.org/licenses/by/4.0/) http://dx.doi.org/10.7575/aiac.alls.v.9n.6p.60 
is willing to fight and die for his country, and in that sense many Native Americans enlisted in the military so as to assert their masculinity. Tayo reflects upon the new attitude of white women toward him after he enlists in the military and how they "came crowding around" (Silko 40) after they saw him wearing the military uniform.

The Machiavellian and manipulative approach used to draft Tayo into the war is only a part of a larger scheme that is always used to only maintain white supremacy and interest with the least loss by the white population. The white apparatus plays into the ideals of American bravery and masculinity to convince Native Americans to fight for the United States. What is sad and ironic is that the United States used Native Americans to fight for them during World War II. Those Native American patriots who America had discriminated against came out and fought for a country that diminished their contributions, "The destroyers had sent them into this world, and day by day were doing it" (Silko 204).

It is until late that Tayo comes to understand this contradiction in the policies and false values of the American system in general:

He wanted to scream at Indians like Harley and Helen Jean and Emo that while things they admired and desired so much - the bright city lights and loud music, the soft sweet food and the cars-all these things had been stolen, torn of the Indian land; raw living materials for thei ck'o'yo manipulation. (Silko 204)

Native Americans went through psychological as well as physical violence. Tayo is subject to post-war trauma as a result of what he has seen during the war. Silko concentrates on the importance of the healing and therapy through constructions of cultural memory, Native American history, and ethnic identity in Ceremony. In her exciting seminal novel, she explores the great roles of both collective and personal memory as well as of a multiple heritage in the de/construction of hybrid ethnic identities that in turn is a healing device for collective trauma. Ceremony tells the story of Tayo who is alienated from his environment and community due to the unbearable war trauma. The violence Tayo has suffers is not only deeply inscribed in his mind, but also affects his physical being; the protagonist is destined to grapple with the many conflicting aspects of his hybrid ethnic body in order to retain a healthy state of being after being a victim of the double standard treatment of the American political, social, economic, ethnographic, and cultural apparatuses.

The memory is the kernel in which past events and experiences, be they happy or sad, are kept and retrieved afterwards. The atrocities of the horrible war Tayo fought keep recurring, deteriorating his very mental stability. Betonie, the medicine man, teaches Tayo to remember everything he has seen during the war: the stories of the war as well as those he chooses to inherit from his own past Native American oral tradition. He remembers the stories his uncle Josiah told him while he was young and also the stories of the land of the Laguna Pueblo that are produced by a White hegemonic discourse. In his article "Memory and Cultural Translation," Gabriel Motzkin states that:

... the memory of the constituted other [in this case, of the white world] is necessary for the definition of self, but this memory itself is so traumatic that it can only be cured through the therapeutic mediation of the transformed other. (271)

The psychological and bodily effects are fed by past memory; that is full with negative experiences in Tayo's case. A horrible experience whose excessive quality overwhelms the psychophysical capacity of a person destroys the very possibility of an integral constitution of self in the aftermath.

In Ceremony, the reader learns that the protagonist, Tayo, comes back from the Philippine horrible and fierce battlefields to his homeland, the Laguna Pueblo reservation. The battles against Japanese soldiers during World War II, in which Tayo lost his dearest and closest cousin Rocky, have cataclysmically traumatized him. Because the white doctors at the Veteran's Hospital in Los Angeles are unable to help him, he is sent back to his reservation, where he finds himself just as alienated from the outside world as in the hospital. Tayo even expresses the desire to return to the veterans' hospital, because uneasy "visions and memories of the past did not penetrate there" (Silko 15). Leslie Silko eruditely and skillfully employs metaphors of white smoke at this point in order to fully describe Tayo's turbulent and tortured state of mind after all that he had gone through in a war that is not his, but a war of the white man to build his empire:

He had drifted in colors of smoke, where there was no plan, only pale, pale gray of the north wall by his bed. Their medicine drained memory out of his thin arms and replaced it with a twilight cloud behind his eyes. It was not possible to cry on the remote and foggy mountain. If they had not dressed him and led him to the car, he would still be there, drifting along the north wall, invisible in the gray twilight. (Silko 15)

Young Native Americans identity is threatened by the white dominant identity. Many of them tried to assimilate into the white culture and let go of their traditions and heritage. White culture appeals to the young generation of Native Americans because they think that they will be welcomed as full American citizens in the new cultural territory. Rocky is a good example of the erosive affect of the white culture on young Native Americans. Like many of his fellow young Native Americans on the reservation, he has always wanted to be as white as possible. Rocky struggles for full integration into the White system and thus tries to deny the legacies of the Pueblo:

[Rocky] was an A-student and all-state in football and track. He had to win; he said he was always going to win... Rocky understood what he had to do to win in the white outside world... Tayo saw how Rocky deliberately avoided the old-time ways. (Silko 51)

This ambivalent identity is a severe tool that leaves Native Americans lost between two warring selves, their Native American world and the white world of America. Those who try to pass for white dominant culture will not be fully accepted and they loose contact with their past heritage. They live in the gray area where their identity is vague and blurred due to the glamorous attractiveness of the white culture.

Rocky tries as hard as he could to forget where he comes from by "whitewashing" himself; his incentive to fight for 
"the white people's war" (Silko 36) is part of this process of assimilating into the white lifestyle. In its time of need, the army promises that "they were American" and "this was the land of the free just like the teachers said in school" (Silko 42).

The magnitude of victimization of Tayo is so strong that he is never the same after the war. The traumatized protagonist is a symbol of the victimization of the collective population of the Native Americans who suffered for five hundred years on the hand of the white man in the name of civilizing the 'brute'. The war experiences are inscribed deeply in Tayo and his fellow ex-veterans psychologically as well as physically. As soon as Tayo tries to remember what he has gone through in the war that destroyed him as much as the Americans destroyed the history and traditions of his Indian people, he starts to tremble, to vomit, to faint:

He felt the shivering then; it began at the tips of his fingers and pulsed into his arms. He shivered because all the facts, all the reasons made no difference anymore; he could hear Rocky's words, and he could follow the logic of what Rocky said, but he could not feel anything except a swelling in his belly, a great swollen grief that was pushing into his throat. (Silko 8-9)

Because ethnicities in the United States has long been marginalized and alienated, members of ethnicities have to negotiate their status in America. In Ceremony, Silko uses various characters of mixed ancestry and emphasizes their outstanding qualities as agents of cultural, social, and historical transition in America. Rachel Stein stresses the fact that Silko portrays the way victimized and marginalized people struggle to reconcile their cultural and social realities and cope with the realities, values, prejudices, politics, racism, and superiority of the dominant white culture of America:

it is often people at the margins of tribal/dominant culture-people of mixed descent... those who bear the conflict between cultures in their own persons and who must inevitably negotiate the entanglement of competing cultures-who are driven to create new stories that reframe the relations of native culture and dominant white culture. (122)

While Rocky dies at the war with the Japanese in the Philippines, many of his Indian comrades survive the war, but they have to realize that without the uniform, they are again considered unwanted Americans as they were before the war. Their disappointment and their hatred for the White world turn against Tayo because he is part White according to his fellow Native Americans who fought with him at the war; Emo, "who prides himself on being a full-breed" (Assmann 65), insults Tayo harshly: "You drink like an Indian, and you're crazy like one too- but you aren't shit, white trash. You love Japs the way your mother loved to screw white men" (Silko 63).

Emo severely criticizes Tayo by using internalized stereotypes that are designed by Whites - the drunk and the crazy Indian. As he cannot dissociate himself from White categorizations, he constantly tries to live up to them and eventually kills Pinkie, one of his friends, in an accident while getting drunk (Silko 259-260). Thus, Emo "becomes one of the displaced and uprooted war-veterans who... succumb to fits of alcohol and aggression" (Assmann 65).
They hybrid identity inflicted upon ethnicities in America is a fierce face of white culture domination and malignant effect on minorities and ethnicities. Therefore, Tayo's victimization becomes a story of refiguring identity within a highly conformist community of Native Americans. This deconstruction of Tayo's social status as victim, a role he has internalized after his traumatic experience at the war, involves a deep and painful confrontation with both his Pueblo and White legacies as conflicting fragments of identity that contradict and collide within him. Thus, the protagonist has to face oppression from both the Laguna community and the White hegemony that seems to be in control of Native American land, culture, and history. The trauma of war has left Tayo estranged not only from his sense of identity, but, as the story unfolds, also from his past, his family and friends, and his homeland. As Aleida Assmann points out that "Ceremo$n y$ is a novel about the relation between trauma and identity. The trauma of war renders the mixed-blooded hero's problem of identity dramatically visible" (290).

All of the surviving veterans are victims of the white world war directly and of the white culture in the general sense indirectly. They are driven to the war by the incentives and promises of the hegemonic white apparatus in time of need and are betrayed by the very system that accumulated false promises of comfortable livelihood. They are haunted by what they have seen: by "what the white people had made from the stolen land" (Silko 169), but also by those who died in the war. They resorted to drinking as a bridge to the oblivion. They want to forget by drinking themselves to a delusional world void of the calamities of the war:

Every day they had to look at the land, from horizon to horizon, and every day the loss was with them; it was the dead unburied, and the mourning of the lost going on forever. So they tried to sink the loss in booze, and silence their grief with war stories about their courage, defending the land they had already lost. (Silko 155)

Temporal borders between the world of the dead and that of the living have become blurred as Tayo is haunted by ghosts of the dead. All ex-veterans are victimized to a degree they resorted to drinking to escape the nightmares and hallucinations inflected upon them by the war. In contrast to his comrades, Tayo does not try to silence and suppress the ghosts of the land and of the war by drinking himself to death. As a cross blood (half Indian, half white) himself, he is familiar with the transgression of borders between binaries like Indian/White, dead/alive, and sanity/insanity, and therefore is able to confront the dead in the course of his trauma therapy and the process of healing through the Native American ceremonies. At the end of the novel, Naomi Rand says, he "chooses a 'voluntary' Indian identity" which "gives him a way of coming to terms with his own dead" (18). This is quite the opposite of what Bigger does in Richard Right's Native Son. Bigger tries to convince himself that he had killed Mary on purpose to justify the abyss he has reached at the end of the book.

Tayo, with the help of the ceremonies of his folks, reshapes his life in away that incorporates his past with his future. He knows that he is a victim of the system, but he feels helpless about it, so he chooses a new way to defeat 
his horrible past and memories. He retells stories of his war experience as well as of his rich Indian heritage. He reconstructs his identity with the help of Betonie and other old Indian people. Unfortunately, Bigger has no access to such rich heritage that values the past and the art of storytelling. Bigger lives with a hostile and ignorant mother and has been left to the huge world that is run by the white man. On the contrary, Tayo invests in his ancestral stories to re/shapes and reconstruct his sense of self, and, in turn, at the end of the book, asks the Laguna elders to re/write tribal history, in order to be able to subvert the negative impact of the white worldviews on Native American culture. As Toni Flores contends in her influential article "Claiming and Making: Ethnicity, Gender, and the Common Sense in Leslie Marmon Silko's Ceremony and Zora Neale Hurston's Their Eyes Were Watching God":

[Tayo] comes to terms with that part of his past which is implicated in the actions of the victimizer-American, violent, male - and with that part which is implicated in the role of the victim-Indian, suffering, female. Resolved to accept neither of these roles, rejecting the necessity of dichotomizing them, he tells the story in a new way, making good rather than evil and active creation rather than passive suffering the salient principles. (120)

Tayo faces a difficult task of distinguishing who is his victimizer, but eventually learns this piece of knowledge. As Jennifer Brice points out: "it is precisely the blurring of self and other that distinguishes him from the destroyers" (32). The construction and creation of the Japanese as enemy to Native Americans is therefore clearly a product of white supremacy and cannot be sustained by Tayo who now is convinced that neither he nor the poor Japanese soldiers are to be blamed for the tribulations and atrocities of the dirty war. The white culture's construction of evil is set to serve the ultimate goals of the white empire that are domination and hegemony. This arbitrary creation of evil, enemy, and witchery is also reflected in the creation myth that is retold in Leslie Silko's great novel, in which White people are believed to be created in an Indian witchery contest between all the tribes of the world: "some had slanty eyes/others had black skin" (Silko133). The Native American myth has it that one of the witches, whose tribe and gender remain unknown, creates the White people as hostile to the world, and so this clearly reveals the fact that evil is a construction. Betonie helps Tayo to understand the nature of witchcraft:

... want[s] us to believe all evil resides with white people. Then we will look no further to see what is really happening. They want us to separate ourselves from white people, to be ignorant and helpless as we watch our own destruction. But white people are only tools that the witchery manipulates; and I tell you, we can deal with white people, with their machines and their beliefs. (Silko132)

The victimization of Native Americans is not exclusive to ordinary people like those in Silko's Ceremony, but also reaches out to the very identity of Native American educated people, namely intellectuals and writers; they also are torn between two warring identities similar to the W.E. Dubois'
'Double Consciousness'. Among the Native American writers and intellectuals, self criticism is being discussed about writing in the mainstream culture and having to live up to the principles and philosophy of the Euro-Americans. Paula Gunn Allen writes: "We had to ask ourselves whether we were really Indian. Maybe not, if we were writers. We had to ask if we were traitors to our Indianness. Maybe we were so assimilated, so un-Indian, that we were doing white folks' work and didn't realize it" (4). The magnitude of Native Americans maltreatment by the white cultural apparatus encompasses all aspects of their lives as will as having dire consequences on Native Americans of all walks of life as it has represented by Tayo in Leslie Silko's novel, Ceremony.

Another example of ethnic victimization is the victimization of the African American population of the United States of America that has endured the most horrible treatment by white people. The fathom of the suffering of colored people is immeasurable. Bigger is a product of corporal as well as geographical victimization. First, he is alienated because of his pigmentation, and second, he is a victim of special segregation, living in a rundown rental building in the poorest part of the city that is dedicated only for black people. In comparison with the hybrid identity of Tayo in Silko's Ceremony, Bigger seems clearer as to the nature of his relation with white people. Simply, he hates them. In an early seen in the novel he asks one of his friends, Gus, rhetorically: "You know where white folks live?"... Bigger doubled his fist and struck his solar plexus. "Right down here in my stomach," he said. "Every time I think of 'em, I feel 'em," (Wright 18).

The white supremacist ideology renders Black people inferior. They were tortured, lynched, burned alive, and most cruelly enslaved for hundreds of years. Bigger is hunted down by thousands of policemen and White mobs. Even after the emancipation of slaves in the United States of America, African Americans were segregated, lynched, and tortured under the eyes of the law and constitution. Wiegman asserts that "In the turn toward lynching as a white supremacist activity in the post-Emancipation years, we might recognize the symbolic force of the white mob's activity as a denial of the black male's newly articulated right to citizenship..." (83). They are considered second rate citizens of the very country that brought them from across oceans to help build the 'land of the free.'

The miserable and lone persona, Bigger, along with his family, is backed into a dark corner of the Black part of the city. The whole family shares a one room apartment infested with rats. They are swamped by poverty, ignorance, discrimination and misunderstanding. Bigger and his family are profoundly frustrated by racism and the limited opportunities afforded black men in society that he ventures out in a futile attempt to transgress the boundaries and limits of his position. Through the estrangement of Bigger Thomas, many of the values and morals of the culture in which he lived are brought to light. Lerone Bennett displays some of the suffering of African Americans in the 'semi-prison' ghettos like the one Bigger lives in:

Deep in the heart of the ghetto, unnoticed by most commentators, things were going from bad to worse. Nearly a third of all Negro homes were dilapidated, as 
compared with less than 10 per cent for the nation as a whole. Worse, more than 20 per cent of all Negro homes were overcrowded. (218)

Bigger is used as representative of his race and class. Wright opens his novel with Bigger killing a fat black rat that has invaded their dilapidated, rotten, one-room apartment. Even as the rat is considered as an intruder to be killed, it is a symbol of the living conditions of urban black America in the ghettos of inner cities and a foreshadowing metaphor for Bigger's psychological condition. The rat has hidden in the Thomas' apartment, growing fat on garbage before it is trapped and killed by Bigger, largely for its physical repulsiveness. Symbolically, the rat is as trapped in the apartment as the family is; both are eating junk food; none may escape and both are ultimately vulnerable to vicious murder. The relationship between the Thomas family and the rat is defined as 'kill or be killed': Bigger's quintessential poor and ignorant colored mother warns him that if he lacks the "manhood" to kill the vicious rat, the rat will "cut our veins at night while we sleep" (8). This relationship, presented at the beginning of the novel, symbolizes Wright's perception of American race relations as evidenced in Bigger Thomas: Bigger is destined to kill whites or be killed; whites must kill Bigger or be killed.

Although Wright's Bigger is hardly a sympathetic character, much less a hero, and he is neither eloquent nor loquacious, he still symbolizes the atrocities of black people. The white dominant culture wants to show justice at the court, and this is why the police refrain from killing Bigger in the first place. The white legal apparatus aims to show to other black folks that any one who attempts any form of heinous crimes against white people will surely face the same end Bigger faces, execution. Richard Wright portrays the values of a culture and society that are accomplices in victimizing Bigger Thomas who is alienated from that culture or society because of race, color, and class. Bigger's alienation reveals the surrounding society's assumptions and moral values.

The latter section of the exquisitely written novel recounts Bigger's trial. His lawyer, a Jewish-American Communist named Boris Max, pleads that Bigger is not responsible for his violent actions because social forces drove him to the abyss of crime, and he urges the judge to spare Bigger the death penalty. The state's prosecutor responds that Bigger is a cold-hearted, depraved criminal and must die as the law requires. The judge rules for the prosecution and sentences Bigger to death. In the final scene, Max attempts to console Bigger, but Bigger rebukes him saying that "What I killed for, I am!" and added "what I killed for must've been good!" (358) Bigger is on blink of insanity to believe that he had killed intentionally and that crimes make him feel better. This is a devastating effect of the victimization of the legal, cultural, and value system of the white world. This portrays the helplessness of Bigger in contrast to the valuable assistant Tayo receives from his community, namely the elderly, the wise, and the medicine people. Tayo's victimization is reconciled at the end while Bigger is left to the racist white apparatus to decide his fate. The decision is termination as is expected by all African American community when confronted by such hatred and prejudice.
The media portrays the normative society as being mainly white, so other minorities are measured against whiteness. Whiteness is the yardstick via which all social, political, economic, and cultural aspects of America are measured. Watching the matinee newsreels, Bigger sees a world of white American luxury and convenience that he is extremely and sadly deprived of as a black person. Such psychological torture is beyond repair in Bigger's case. He tries to make up for this deprivation via violence. He sees a world of "the daughter of the rich taking sun baths in the sands of Florida," a sight that, the commentator informs him, "represents over four billion dollars of America's wealth" (Wright 34). Next to this vision, are both his own experience and the feature film's portrait of "naked black men and women whirling in wild dances" (Wright 36) recede into insignificance. Bigger's mind is instead occupied with an awe-filled longing for that other world, that "real" world of Hollywood fantasies. Consciousness of self and world, as indeed of the black "savages" of B-movies, is here "replaced by images in his own mind of white men and women dressed in black and white clothes, laughing, talking, drinking and dancing" (Wright 36). Not only Trader Horn's African scene, but his own experience as a black American is deeply affected by media-fostered dreams of a white world, a more appealing commodities, beauty, money, and power.

The victimization that leads to violence is the bitterest aftermath one can imagine. Ironically, Bigger finds the first real meaning to his life in his acts of violence. He is no longer dislocated and alienated in society, but identified with no guilt or repentance. For the first time, he feels he has mastered his own fate. Escaping his wretched living space, Bigger finds little peace in his ghetto environs and so he resorted to violence. He believes that his killings have brought order and meaning to his life. This act of will is the shocking culmination of Bigger's revolt against the oppression of white society. He believes that he has finally achieved self-realization. He addresses Max at the trial: "I didn't know I was really alive in this world until I felt things hard enough to kill for 'em," (358).

White supremacist stereotypes of black people are another sheer violation of their humanity. Black males are portrayed as rapists and brutes. Bigger, who admires the Hollywood image of white power, knows well the myths by which such movie figures assume their real power over him and his fellow black Americans. Bigger knows both the myths white America maintains about itself and those by which it defines African American reality. The logic of the lynch mob, the white stereotypes of the black rapist, is hardly new to his consciousness. As he tells Max, all he knows of Mary Dalton is that "they kill us for women like her" (Wright 405), and do so with language of the rape and the black rapist: "They say black men do that. So, it don't matter if I did or if I didn't" (Wright 404). Here racist myth figures both as a determinant of his reality and as part of his own dreaming identification with the white world that produces this oppressive reality. Earlier, admiring and affirming that white power and luxury captured in newsreel images of lounging, billion-dollar debutantes, Bigger in this very endorsement jokes that if friend Jack were indeed part of this fantasy world, "he' $d$ be 
hanging from a tree like a bunch of bananas" (Wright 34).

As a response to the oppression and depravity, Bigger slides to the dark abyss of crime. The question here is who to be blamed; the answer is the long history of segregation and racism against the black people in America. The white discourse renders people of color as inferiors and subhuman. Bigger is an archetypal figure of an oppressed man with no alternatives available to him by the main stream culture. In his article, "The Promise of Democracy in Richard Wright's Native Son," Edwin B. Burgum argues that the new African American is no longer to be taken for granted as submissive and obsequious person. Burgum contends:

He [modern Negro] is on the point of rebellion when he is mistreated. He is watchful for hypocrisy, scornful of the insufficiency of good intention, determined not to sell his birthplace for the small change of petty concessions. The new Negro today feels that the gulf is absolute between the white skin and the black. (113)

Robert Bone explains the sad fate of Bigger through the attitude of Max, the only person who tried hard to overcome the prejudice and blind white legal apparatus:

What terrifies Max is that Bigger, re-possessed by hate, ends by accepting what life has made him: a killer. Bigger's real tragedy is not that he dies, but that he dies in hatred. A tragic figure, he struggles for love and trust against the hostile environment which defeats him in end. (158)

Max is unable to help Bigger out in the same way Betonie help Tayo. We can figure that both characters, Tayo in Leslie Silko's Ceremony and Bigger in Richard Wright's Native Son, are models of white supremacist apparatus' manipulation and victimization, though in different ways. They both have to go through suffering and humiliation with one of them, Tayo, successful in at least temporarily heals from the trauma inflicted upon him with the help of his Native American long tradition of ceremony, and with the other, Bigger, ending in death by execution because he has no access to fair trial and communal help like that Tayo receives from his own community. Therefore, this paper shows that one of the solution to cultural domination and victimization could be achieved through communal support and through reconnecting to ethnic heritage. This reconnection, in its turn, may help in enhancing multiculturalism in America by producing healthy ethnic Americans with positive self-images who are able to integrate into the multicultural social fabric of America, Like in the case of Tayo.

\section{REFERENCES}

Allen, Paula Gunn. ed. Spider Woman's Granddaughters: Traditional Tales and Contemporary Writing by Native American Women. New York: Fawcett Books, 1986.

Ashman, Allied. "Space, Place, Land: Changing Concepts of Territory in English and American Fiction." Borderlands: Negotiating Boundaries in Postcolonial Writing. Ed. Monika Reif-Hulser. Amsterdam: Rodopi, 1999. 57-68.

Bennett, Lerone. "Bigger in Wonderland" Richard Wright's Native Son: A Critical Handbook. Ed. Richard Abcarian. Belmont, California: Wadsworth Publishing Company, Inc., 1970. 214-218.

Bone, Robert B. "Native Son: A Novel of Social Protest" Richard Wright's Native Son: A Critical Handbook. Ed. Richard Abcarian. Belmont, California: Wadsworth Publishing Company, Inc., 1970. 152-159.

Burgum, Edwin B. "The Promise of Democracy in Richard Wright's Native Son." Richard Wright's Native Son: A Critical Handbook. Ed. Richard Abcarian. Belmont, California: Wadsworth Publishing Company, Inc., 1970. 111-122.

Motzkin, Gabriel. "Memory and Cultural Translation." The Translatability of Cultures. Figurations of the Space Between. Ed. Sanford Budick and Wolfgang Iser. Stanford: Stanford UP, 1996. 265-281.

Rand, Naomi R. Silko, Morrison, and Roth. Studies in Survival. New York: Lang, 1999.

Flores, Toni. "Claiming and Making: Ethnicity, Gender, and the Common Sense in Leslie Marmon Silko's Ceremony and Zora Neale Hurston's Their Eyes Were Watching God." Contemporary American Women Writers: Gender, Class, Ethnicity. Ed. Lois Parkinson Zamora. London: Longman, 1998. 114-127.

Silko, Leslie Marmon. Ceremony. New York: Penguin Books Inc., 1977.

Stein, Rachel. Shifting the Ground: American Women Writers'Revisions of Nature, Gender, and Race. Charlottesville, London: UP of Virginia, 1997.

Wiegman, Robyn. American Anatomies: Theorizing Race and Gender. Durham: Duke UP, 1995.

Wright, Richard. Native Son. New York, London: Harper \& Brothers Publishers, 1993. 